\title{
Genetic and Phenotypic Analysis of Borrelia miyamotoi sp. nov., Isolated from the Ixodid Tick Ixodes persulcatus, the Vector for Lyme Disease in Japan
}

\author{
MASAHITO FUKUNAGA, ${ }^{1}{ }^{*}$ YUKIE TAKAHASHI,${ }^{1}$ YASUTO TSURUTA, ${ }^{1}$ OSAMU MATSUSHITA, ${ }^{2}$ \\ DAVID RALPH, ${ }^{3}$ MICHAEL MCCLELLAND, ${ }^{3}$ AND MINORU NAKAO ${ }^{4}$ \\ Faculty of Pharmacy and Pharmaceutical Sciences, Fukuyama University, Fukuyama, Hiroshima 729-02, ${ }^{1}$ \\ Department of Microbiology, Kagawa Medical School, Ikenobe, Kita-gun, Kagawa 761-07, ${ }^{2}$ and \\ Department of Parasitology, Asahikawa Medical College, Nishikagura, Hokkaido 078, ${ }^{4}$ \\ Japan, and California Institute of Biological Research, La Jolla, California $92037^{3}$
}

\begin{abstract}
The ixodid tick Ixodes persulcatus is the most important vector of Lyme disease in Japan. Most spirochete isolates obtained from I. persulcatus ticks have been classified as Borrelia burgdorferi sensu lato because of their genetic, biological, and immunological characteristics. However, we found that a small number of isolates obtained from I. persulcatus contained a smaller 38-kDa endoflagellar protein and single 23S-5S rRNA gene unit. Representative isolate $\mathrm{HT}^{\mathrm{T}}{ }^{\mathrm{T}}$ ( $\mathrm{T}=$ type strain) had the same $23 \mathrm{~S}$ rRNA gene physical map as Borrelia turicatae. The DNA base composition of strain $\mathrm{HT31}^{\mathrm{T}}$ was $28.6 \mathrm{~mol} \% \mathrm{G}+\mathrm{C}$. DNA-DNA hybridization experiments revealed that strain $\mathrm{HT}^{\mathrm{T}}{ }^{\mathrm{T}}$ exhibited moderate levels of DNA relatedness $(24$ to $51 \%)$ with Borrelia hermsii, B. turicatae, Borrelia parkeri, and Borrelia coriaceae. However, the levels of DNA reassociation with the previously described Lyme disease borreliae (B. burgdorferi, Borrelia garinii, and Borrelia afzelii) were only 8 to $13 \%$. None of the previously described species examined exhibited a high level of DNA relatedness with strain HT31 $^{\mathrm{T}}$. In addition, the 16S rRNA gene sequence (length, 1,368 nucleotides) of strain $\mathrm{HT31}^{\mathrm{T}}$ was determined and aligned with the 16S rRNA sequences of other Borrelia species. Distance matrix analyses were performed, and a phylogenetic tree was constructed. The results showed that isolate HT31 ${ }^{\mathrm{T}}$ is only distantly related to both previously described Lyme disease borreliae and relapsing fever borreliae. Thus, the spirochetes isolated from I. persulcatus and closely related isolates should be classified as members of a new Borrelia species. We propose the name Borrelia miyamotoi sp. nov. for this spirochete; strain HT31 is the type strain.
\end{abstract}

We previously demonstrated the usefulness of a restriction fragment length polymorphism (RFLP) ribotyping system based on the 23S-5S rRNA gene repetition in Borrelia burgdorferi sensu lato associated with Lyme disease $(14,32)$. Many spirochete isolates were examined with our RFLP ribotyping system by using rRNA gene probes. The strains isolated in the United States and Europe were placed into three distinct RFLP groups. The North American isolates clustered in ribotype group I (B. burgdorferi sensu stricto), and the European isolates were placed in ribotype groups I and II (Borrelia garinii) and ribotype group III (Borrelia afzelii). These groups are completely consistent with the three previously described Lyme disease agent species $(2,7,18)$. Our findings also showed that there are no $B$. burgdorferi sensu stricto representative strains in Japan and that some Japanese isolates belong to ribotype groups II and III. In addition, most of the Japanese isolates produced RFLP patterns that were quite distinct from those of the North American and European isolates and were tentatively classified as ribotype group IV strains (14). Borrelia japonica is carried by Ixodes ovatus ticks, and it is thought that this microorganism is restricted to Japan. Moreover, some atypical spirochetes have been isolated in United States and Europe (38), and these spirochetes produced unique RFLP ribotype patterns.

Two medically important diseases, relapsing fever and Lyme borreliosis, are caused by Borrelia species (4). Both of these

* Corresponding author. Mailing address: Department of Molecular Microbiology, Faculty of Pharmacy and Pharmaceutical Sciences, Fukuyama University, Gakuencho 1-1, Fukuyama, Hiroshima 729-02, Japan. Phone: 8184936 2111. Fax: 8184936 2024. Electronic mail address: mfukunag@ddbj.nig.ac.jp. diseases are transmitted by hematophagous arthropods, and each pathogen is associated with particular vectors. Soft-bodied argasid ticks and the human body louse are the vectors of relapsing fever borreliae, while the vectors of Lyme disease borreliae are hard-bodied ixodid ticks, especially members of the Ixodes ricinus species complex $(6,17)$. The Borrelia pathogens differ in their clinical spectra. Periodic fever is the main symptom caused by relapsing fever borreliae (4); these organisms multiply in the bloodstream, and they have a high mutation rate in the genes which encode the outer membrane proteins and thus escape the host immune response. In contrast, Lyme disease borreliae cause various inflammatory reactions involving the skin, joints, heart, and central nervous system (22, 43); emergence of these borreliae into the bloodstream is rare, suggesting that they have a unique mechanism to escape the host immune response. Thus, the two related pathogens are quite different from one another in their adaptations to their arthropod and vertebrate hosts.

In our experimental survey, we found that a small number of the spirochetes examined contained a $38-\mathrm{kDa}$ flagellin protein similar to that found in relapsing fever borreliae; in contrast, a $41-\mathrm{kDa}$ flagellin protein is found in previously described Lyme disease borreliae. In this paper we describe the genetic and phenotypic characteristics of spirochetes isolated from Ixodes persulcatus ticks and a rodent. We also describe the results of a comparative $16 \mathrm{~S}$ rRNA gene sequence analysis and a DNADNA relatedness analysis in which we identified strain HT31 ${ }^{\mathrm{T}}$ ( $\mathrm{T}=$ type strain) and related isolates as members of a new Borrelia species. Our results indicated that these spirochete isolates obtained from $I$. persulcatus actually belong to a new Borrelia species. We propose the name Borrelia miyamotoi for this new species. 
TABLE 1. Organisms used in this study

\begin{tabular}{|c|c|c|}
\hline \multirow{2}{*}{ Strain or species } & \multicolumn{2}{|r|}{ Source } \\
\hline & Location & Organism \\
\hline \multicolumn{3}{|l|}{ Japanese isolates } \\
\hline HT24 & Hokkaido, Japan & Ixodes persulcatus \\
\hline HT $31^{\mathrm{T}}$ & Hokkaido, Japan & Ixodes persulcatus \\
\hline Hk004 & Hokkaido, Japan & Ixodes persulcatus \\
\hline NB103/1 & Hokkaido, Japan & Ixodes persulcatus \\
\hline FR64b & Hokkaido, Japan & Apodemus argenteus \\
\hline \multicolumn{3}{|l|}{ B. japonica strains } \\
\hline Am 105 & Aomori, Japan & Ixodes ovatus \\
\hline $\mathrm{HO}^{\mathrm{T}}\left(=\mathrm{JCM} 8951^{\mathrm{T}}\right)$ & Hokkaido, Japan & Ixodes oratus \\
\hline IKA2 & Shizuoka, Japan & Lxodes ovatus \\
\hline $\begin{array}{l}\text { B. burgdorferi sensu stricto } \\
\text { strain B31 }{ }^{\mathrm{T}} \text { (= ATCC } \\
\left.35210^{\mathrm{T}}\right)\end{array}$ & United States & Ixodes scapularis \\
\hline $\begin{array}{l}\text { B. garinii } 20047^{\mathrm{T}}(=\mathrm{CIP} \\
\left.103362^{\mathrm{T}}\right)\end{array}$ & France & Ixodes ricinus \\
\hline $\begin{array}{l}\text { B. afzelii VS } 461^{\mathrm{T}}(=\mathrm{CIP} \\
\left.103469^{\mathrm{T}}\right)\end{array}$ & Switzerland & Ixodes ricinus \\
\hline $\begin{array}{l}\text { Unnamed genomospecies } \\
\text { strain DN127 }\end{array}$ & United States & Ixodes pacificus \\
\hline B. hermsii & United States & Ornithodoros hermsi \\
\hline B. turicatae & United States & Omithodoros turicata \\
\hline B. parkeri & United States & Ornithodoros parkeri \\
\hline B. coriaceae Co53 & United States & Omithodoros coriaceus \\
\hline B. anserina & Unknown & Argas persicus \\
\hline
\end{tabular}

\section{MATERIALS AND METHODS}

Bacterial strains and culture conditions. Spirochete isolates were obtained by culturing $I$. persulcatus midgut tissues or rodent blood in BSKII medium at $31^{\circ} \mathrm{C}$. B. japonica Am 105 isolated from I. ovatus midgut tissue (45), B. japonica IKA2 and $\mathrm{HO} 14^{\mathrm{T}}(25)$, and unnamed genomospecies DN127 (38) were also used in this study. All of the other Borrelia strains used were provided by R. C. Johnson (University of Minnesota) and G. Baranton (Institut Pasteur, Paris, France). All of the strains used in this study are shown in Table 1.

SDS-PAGE and Western blotting. Whole-cell lysates of spirochetes were analyzed by sodium dodecyl sulfate (SDS)-polyacrylamide gel electrophoresis (PAGE) and Westem blotting (immunoblotting) as described previously $(13,33$, 34). Monoclonal antibody H9724 was used as the probe in the Western blot analysis. Monoclonal antibody $\mathrm{H} 9724$ reacts with a protein in borrelial periplasmic flagella (5).

DNA purification. Cells were cultivated in $100 \mathrm{ml}$ of BSKII medium for 7 to 14 days at $31^{\circ} \mathrm{C}$ and harvested by centrifugation (13). Total DNA was extracted as described previously (11). Deproteinized DNA was dissolved in $200 \mu \mathrm{l}$ of TE buffer $(10 \mathrm{mM}$ Tris-HCl, $1 \mathrm{mM}$ EDTA; $\mathrm{pH} 8.0)$ and mixed with $5 \mu \mathrm{l}$ of RNase $(1 \mathrm{mg} / \mathrm{ml})$. After incubation for $30 \mathrm{~min}$ at $37^{\circ} \mathrm{C}$, the DNA solution was mixed with $120 \mu$ of a polyethylene glycol solution ( $20 \%$ polyethylene glycol [molecular weight, 8,000 to approximately 10,000$], 2.5 \mathrm{M} \mathrm{NaCl}$ ) and chilled in ice for $1 \mathrm{~h}$. The DNA was precipitated by centrifugation and washed with $900 \mu \mathrm{l}$ of $70 \%$ ethanol. The DNA was then dried and dissolved in $50 \mu \mathrm{l}$ of TE buffer. A small aliquot of DNA was electrophoresed in an agarose gel and stained with ethidium bromide. The DNA concentration was determined by densitometry (ATTO Co., Ltd., Osaka, Japan).

Southern blot hybridization. Spirochete DNAs were digested with EcoRV or HinclI, electrophoresed, and transferred to a membrane as described previously (12). The 23S rRNA gene probes of $B$. burgdorferi $B 31^{\top}$ designated NP and Sty were labeled with $\left[\alpha-{ }^{32} \mathrm{P}\right] \mathrm{dCTP}$ as described previously and then used for hybridization (14)

PFGE. Spirochetes were grown in $100 \mathrm{ml}$ of BSKII medium at $31^{\circ} \mathrm{C}$, collected by centrifugation, washed, and used immediately for pulsed-field gel electrophoresis (PFGE). The procectures used to prepare high-molecular-weight genomic DNAs have been described previously (45). Genomic DNAs in plugs were cleaved and electrophoresed in a $0.5 \times$ TBE $(1 \times$ TBE is $89 \mathrm{mM}$ Tris, 89 $\mathrm{mM}$ boric acid, and $2 \mathrm{mM}$ EDTA (pH 8.3])-buffered contour-clamped homogeneous electric field model DRII apparatus (Bio-Rad Laboratories, Richmond, Calif.) as described previously (45). Molecular size markers consisting of lambda phage DNA concatemers or low-range PFG markers (New England Biolabs, Beverly, Mass.) were used to calculate the sizes of the fragments.

G $+\mathbf{C}$ content of DNA. The $G+C$ content was determined by high-performance liquid chromatography (HPLC). A DNA preparation was dissolved in distilled water and boiled for $5 \mathrm{~min}$. After the sample was chilled in ice, $10 \mu \mathrm{l}$ ( 3 to $\sim 5$ $\mu \mathrm{g}$ ) of denatured DNA was degraded with nuclease P1 (DNA-GC kit; Seikagaku
Kogyo, Tokyo, Japan) according to the manufacturer's instructions. The hydrolysate and a standard solution $(10 \mu \mathrm{l}$ each) were subjected to HPLC in a Shimadzu model LC-10AS apparatus by using a YMC pack AQ-312 column ( 6 by $150 \mathrm{~mm}$; YMC Co., Ltd., Kyoto, Japan). The mobile phase used was $10 \mathrm{mM}$ phosphate buffer ( $\mathrm{pH} 3.5$ ), and the flow rate was $1.5 \mathrm{ml} / \mathrm{min}$. The $A_{270}$ of the effluent was monitored with a Shimadzu model SPD-10A UV-visible light detector.

DNA-DNA hybridization. Levels of DNA reassociation were determined by the membrane filter method (26). A $2-\mu \mathrm{g}$ portion of DNA was loaded onto a nylon membrane (Zeta probe membrane; 15 by $15 \mathrm{~mm}$; Bio-Rad Laboratories) and denatured twice with $0.5 \mathrm{M} \mathrm{NaOH}$. The membrane was then neutralized twice with $1 \mathrm{M}$ Tris- $\mathrm{HCl}(\mathrm{pH} 7)$, dried at $65^{\circ} \mathrm{C}$ for $30 \mathrm{~min}$, and used for hybridization experiments (11). The DNA was labeled with $\left[1^{\prime}, 2^{\prime}, 5^{\prime}-{ }^{3} \mathrm{H}\right] \mathrm{dCTP}(2.37$ $\mathrm{TBq} / \mathrm{mmol}$; Amersham Japan, Ltd., Tokyo, Japan) by using a random primer labeling kit (Takara Shuzo Co., Ltd., Kyoto, Japan) as described previously, and this DNA was used as a probe. The filter membrane containing bound DNA was incubated at $60^{\circ} \mathrm{C}$ for $5 \mathrm{~h}$ in hybridization buffer containing $10 \%$ dextran sulfate (Pharmacia, Uppsala, Sweden), $1 \%$ SDS, $1 \mathrm{M} \mathrm{NaCl}$, and $100 \mu \mathrm{g}$ each of salmon sperm DNA and yeast RNA per ml (10). The membrane was then hybridized with the radiolabeled probe at $60^{\circ} \mathrm{C}$ for $15 \mathrm{~h}$. After hybridization, the membrane was washed twice with $6 \times \mathrm{SSC}(1 \times \mathrm{SSC}$ is $0.15 \mathrm{M} \mathrm{NaCl}$ plus $0.015 \mathrm{M}$ sodium citrate, $\mathrm{pH} 7)$ and three times with $2 \times \mathrm{SSC}$ at $60^{\circ} \mathrm{C}$ for $30 \mathrm{~min}$. The filter membrane was then dried and counted with a liquid scintillation counter by using $10 \mathrm{ml}$ of scintillation cocktail. Three experiments were performed independently, and the results were normalized by homologous DNA hybridization.

Cloning the 16S rRNA gene and sequencing. The nucleotide primers which we used (5'-GCT GGC AGT GCG TCT TAA GCA TGC-3' [positions 35 to 58, Escherichia coli numbering] and 5'-GTG ACG GGC GGT GTG TAC AAG GCC C-3' [positions 1384 to 1408]) were synthesized and used for PCR amplification. PCR amplification was performed in a $100-\mu$ l reaction mixture for 30 cycles in a thermal controller (ATTO Zymoreactor) by using a denaturation step $\left(94^{\circ} \mathrm{C}\right.$ for $\left.40 \mathrm{~s}\right)$, an annealing step $\left(45^{\circ} \mathrm{C}\right.$ for $\left.30 \mathrm{~s}\right)$, and an extension step $\left(72^{\circ} \mathrm{C}\right.$ for $45 \mathrm{~s})$. The other experimental conditions were the same as those described previously (14). A DNA fragment obtained by PCR amplification was purified as described above (polyethylene glycol precipitation), was ligated into vector plasmid pGEM5Zf by using a pGEM-T vector cloning kit (Promega Biotech, Madison, Wis.), and then introduced into competent E. colt JM109 cells by following the manufacturer's instructions. The nucleotide sequence was determined by the dideoxy chain termination method; the preparation was primed with a series of custom-synthesized primers by using an Autoread sequencing kit and an ALFred sequencer (Pharmacia). The sequences of both strands of two independent clones were determined by using custom primers. No differences in the sequences of the two clones were observed.

Different protocols were used to determine the sequences of strains DN127, IKA2, and HO14 ${ }^{\mathrm{T}}$. PCR primers 16S-1507 (5'-CCA GAT CTG AGC TCA AGG AGG TGA TCC AGC-3') and 16S-11 (5'-GGC TGC AGT CGA CGT TTG ATC CTG GCT CAG-3') were used to amplify the 16S rRNA genes from $10 \mathrm{ng}$ of Borrelia genomic DNA. These primers contained a Bglll site and a SalI site, respectively, and these sites were used for cloning. The PCR conditions were as follows: 30 cycles consisting of a denaturation step $\left(94^{\circ} \mathrm{C}\right.$ for $\left.1 \mathrm{~min}\right)$, an annealing step $\left(55^{\circ} \mathrm{C}\right.$ for $\left.1 \mathrm{~min}\right)$, and an extension step $\left(72^{\circ} \mathrm{C}\right.$ for $\left.2 \mathrm{~min}\right)$. The PCR products were extracted with phenol-chloroform, precipitated, redissolved in water, and digested sequentially with BglII and SalI. Ligation with vectors Bluescript SK and KS (Stratagene) and transformation into XL1-blue cells (Stratagene) were performed by following the instructions of the manufacturer. Templates for sequence determinations were prepared as phagemids rescued from insert-containing clones. Cloning into the two vectors permitted both orientations to be sequenced, and sequences were determined by using a Sequenase kit (U. S. Biochemicals, Cleveland, Ohio) and $\alpha{ }^{-35} \mathrm{~S}$-dATP. Sequencing reaction mixtures were primed either with vector-encoded universal or RV primers or with a series of custom-synthesized primers spaced uniformly across the entire gene. At least two clones (and up to four clones) were sequenced for each PCR product.

Multiple alignments of the sequences were prepared, and a neighbor-joining phylogenetic tree (39) was constructed by using the DNASTAR program

(DNASTAR, Inc., Madison, Wis.) and the Clustal method (16).

Nucleotide sequence accession numbers. The $16 \mathrm{~S}$ rRNA gene sequence of strain $\mathrm{HT} 31^{\mathrm{T}}$ has been deposited in the GSDB, DDBJ, EMBL, and NCBI data libraries under accession number D45192. The GenBank accession numbers for the $16 \mathrm{~S}$ rRNA gene sequences of strain DN127 and B. japonica HO14 ${ }^{\mathrm{T}}$ and IKA2 are $\mathrm{L} 40596, \mathrm{~L} 40597$, and $\mathrm{L} 40598$, respectively. The accession numbers for the reference sequences which we used are as follows: $B$. burgdorferi $\mathrm{B} 31^{\mathrm{T}}$, M59293; B. burgdorferi 1352, M64309; B. garinii G1, M64311; B. afzelii Ip3, M75149; Borrelia hermsii HS1, M60968; Borrelia coriaceae, M60970; and Borrelia anserina, M64312.

\section{RESULTS AND DISCUSSION}

Unfed ticks were collected by flagging or dragging vegetation in various locations in Hokkaido, the northern island of Japan, where Lyme disease is endemic $(27-32)$. Ticks were collected from birds at Nemuro, Hokkaido, Japan, with the 


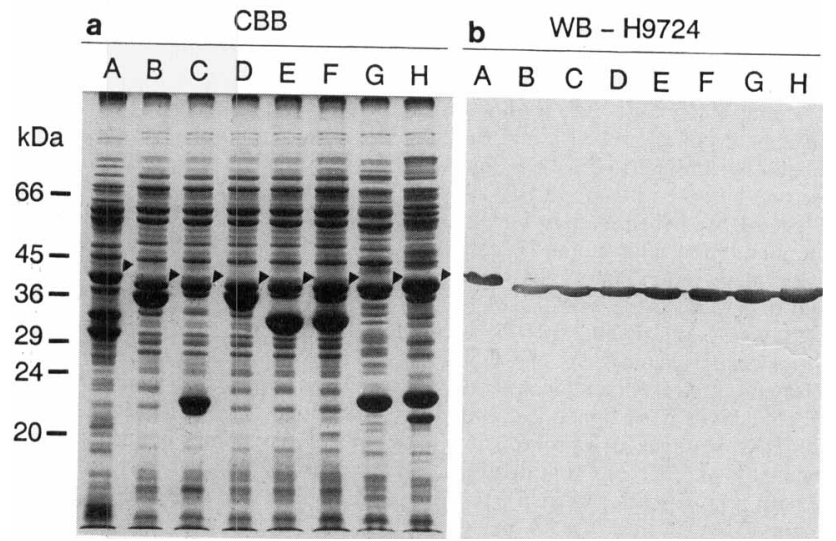

FIG. 1. Coomassie brilliant blue-stained proteins in whole-cell lysates of borrelial isolates and antigenic characteristics with monoclonal antibody H9724. An SDS-PAGE analysis (a) and a Western blot analysis (b) were performed as described previously $(33,34)$. Murine monoclonal antibody H9724 was obtained as a hybridoma supernatant. Lane A, B. burgdorferi B31 ; lane B, strain HT24, lane C, strain HT $31^{\mathrm{T}}$; lane D, strain Hk004; lane E, strain NB103/1; lane F, strain FR64b; lane G, B. hermsii; lane H, B. anserina. The positions of molecular mass standards are indicated on the left. The arrowheads indicate the position of the protein that reacted with monoclonal antibody H9724. CBB, Coomassie brilliant blue; WB-H9724, Western blot with monoclonal antibody H9724.

collaboration of many bird banders. Mice were captured in Sherman box traps as described previously (31). Spirochetes were grown by culturing tick midgut tissues or rodent blood in BSKII medium (3) at $31^{\circ} \mathrm{C}$. The origins of the five isolates which we studied are as follows: strain HT24, an unfed female tick collected at Shiretoko, Hokkaido, Japan; strain HT31 ${ }^{\mathrm{T}}$, an unfed female tick collected at Shiretoko, Hokkaido, Japan; strain Hk004, an unfed tick nymph collected at Shibecha, Hokkaido, Japan; strain NB103/1, a tick nymph that fed on a bird (Emberiza spodocephala) captured at Nemuro, Hokkaido, Japan; and strain FR64b, blood from a rodent (Apodemus argenteus) trapped at Furano, Hokkaido, Japan. All culture sources were collected from 1990 through 1992.

The molecular weight of the endoflagellar protein was estimated from the results of SDS-PAGE and Western blotting (Fig. 1). Monoclonal antibody H9724, which is specific for Borrelia flagellar protein, was used as a probe for Western blotting. Although a $41-\mathrm{kDa}$ flagellar protein is found in previously described Lyme disease borreliae, the five isolates obtained in Hokkaido contained a $38-\mathrm{kDa}$ flagellar protein similar to that found in relapsing fever borreliae.

The rRNA genes of the B. burgdorferi sensu lato strains associated with Lyme disease have a unique organization. Two sets of $23 \mathrm{~S}$ and $5 \mathrm{~S}$ rRNA genes are repeated directly, are $3.2 \mathrm{~kb}$ long, and are separated from the single $16 \mathrm{~S}$ rRNA gene $(9,15$, 42). As shown in Fig. 2A and C, two hybridization signals were detected in the Lyme disease borreliae that produced the $3.2-\mathrm{kb}$ band. In contrast, genomic Southern hybridization of the new spirochete isolates used in this study yielded a single radioactive band for each isolate. It has been shown that there is only one copy of the 23S and 5S rRNA genes in relapsing fever borreliae (42). We constructed physical maps of the rRNA genes and their flanking regions for our spirochetes, and the maps revealed that there is a single gene unit, indicating that the $23 \mathrm{~S}$ and 5S rRNA genes are not repeated. We performed an RFLP analysis associated with the rRNA gene tandem cluster (12-15). The sizes of the restriction bands were determined, and the borrelial isolates were classified into several RFLP ribotype groups. This RFLP analysis in which tan- dem repetition was used was useful for identifying closely related Borrelia isolates, and all B. burgdorferi sensu lato isolates associated with Lyme disease exhibited this unique rRNA gene repetition $(14,42)$. However, the spirochete isolates obtained in Hokkaido and the relapsing fever borreliae produced a single band, indicating that the 23S-5S rRNA gene unit was not repeated (Fig. 2A).

Physical maps of the rRNA genes and flanking regions of representative strain $\mathrm{HT} 31^{\mathrm{T}}$ and Borrelia turicatae were constructed by using a previously described method (15). As shown in Fig. 2B, the restriction sites in the $23 \mathrm{~S}$ rRNA gene were identical in these two borreliae, but the restriction sites in the flanking region were different. We also examined the rRNA gene organization of other borreliae, including $B$. anserina, Borrelia parkeri, $B$. hermsii, and $B$. coriaceae, and no repetition was observed in any of these organisms (data not shown). The organization of rRNA genes has also been described by other workers $(9,42)$. The organization of rRNA genes is highly conserved among prokaryotes, and the three rRNA genes are closely linked in the gene set in the following order: 16S-23S-5S (35). In contrast, in the genus Borrelia, the $16 \mathrm{~S}$ rRNA gene is separated from the other two rRNA genes, and it is thought that tandem repetition of the $23 \mathrm{~S}$ and $5 \mathrm{~S}$ rRNA genes is limited to Borrelia species that infect ixodid ticks. However, an exception has been described by Liveris et al. (21), who found that gene duplication was absent in $B$. japonica IKA2 isolated from an I. ovatus tick in Japan. All five isolates obtained in Hokkaido had the same physical map (data not shown).

Spirochete genomic DNAs were digested with restriction enzymes MluI, ApaI, and SalI and separated by PFGE. The fragment configurations obtained with $M l u \mathrm{I}$ are shown in Fig. 3; when the other endonucleases were used, the five isolates obtained in Hokkaido produced the same PFGE profiles (data not shown). When MluI, ApaI, and Sall were used, the PFGE profiles of the five isolates obtained in Hokkaido were different from the profiles of the previously described Lyme disease and relapsing fever borreliae. The PFGE gels were then blotted and hybridized with Lyme disease borrelia-specific gene probe P39 provided by T. G. Schwan (Rocky Mountain Laboratories) (40). This probe hybridized with previously described Lyme disease borreliae but not with the five isolates obtained in Hokkaido or with the relapsing fever borreliae (data not shown).

The relative binding ratios obtained in hybridization experiments performed by using the membrane filter method are shown in Table 2. The levels of hybridization between labeled strain HT31 ${ }^{\mathrm{T}}$ genomic DNA and DNAs from strains $\mathrm{B} 31^{\mathrm{T}}$, $20047^{\mathrm{T}}$, VS461 ${ }^{\mathrm{T}}$, and Am105 ranged from 8 to $13 \%$. The genomic DNA of strain HT31 ${ }^{\mathrm{T}}$, which was isolated from $I$. persulcatus, was quite similar to the DNA of strain FR64b, which was isolated from $A$. argenteus blood. Representatives of $B$. hermsii, B. turicatae, B. parkeri, B. coriaceae, and B. anserina exhibited levels of relatedness of 24 to $51 \%$ with strain HT31 ${ }^{\mathrm{T}}$. The levels of DNA similarity between labeled strain B31 DNA and DNAs from strains $20047^{\mathrm{T}}$, VS461 ${ }^{\mathrm{T}}$, and Am105 were similar to values obtained in previous reports $(2,19)$, which supported the validity of the data which we obtained. It is generally assumed that the level of DNA similarity for two separate species should be less than $70 \%$ under optimal conditions (47). The results of our DNA-DNA hybridization experiments suggest that strain HT31 $1^{\mathrm{T}}$ isolated from $I$. persulcatus actually represents a new Borrelia species.

We cloned the $16 \mathrm{~S}$ rRNA gene of strain HT31 ${ }^{\mathrm{T}}$ and the nucleotide sequence was determined in order to quantitatively assess the level of phylogenetic divergence of this strain from 
A

\section{$\begin{array}{llllllllll}1 & 2 & 3 & 4 & 5 & 6 & 7 & 8 & 9 & 1011\end{array}$}

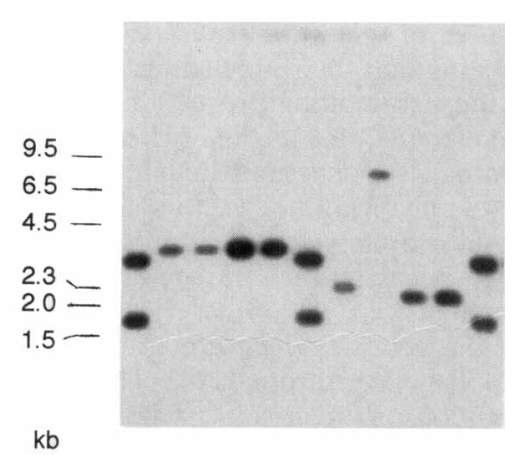

B

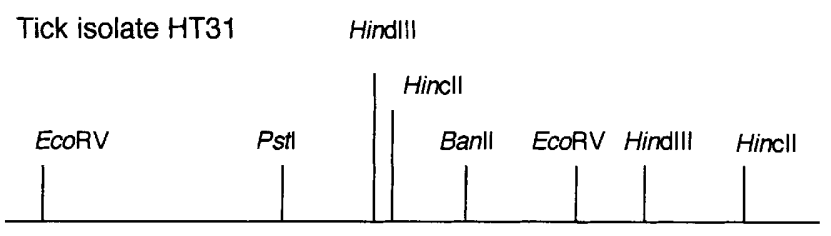

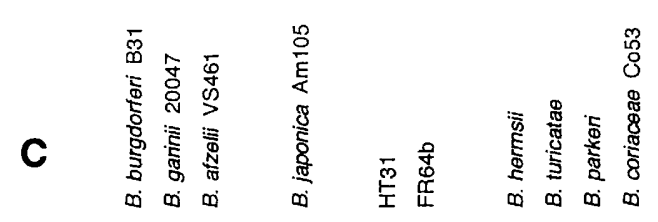

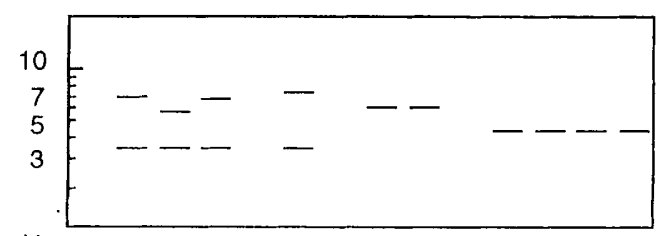

$\mathrm{kb}$

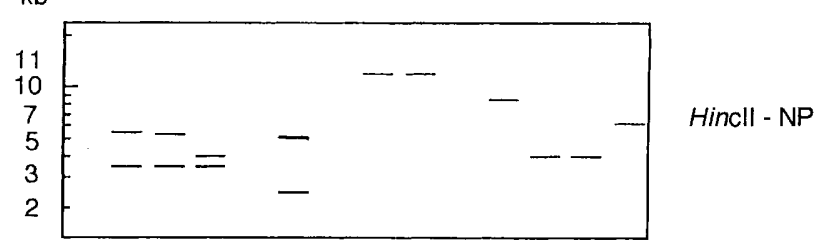

$\mathrm{kb}$

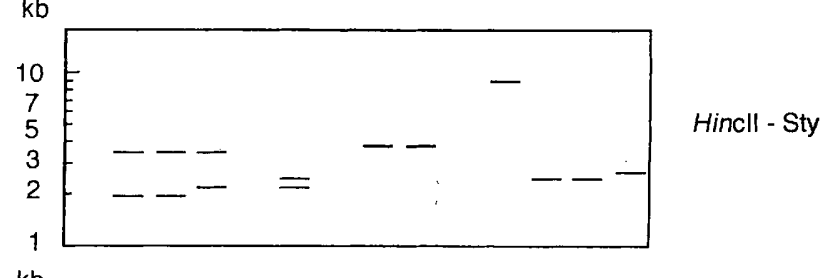

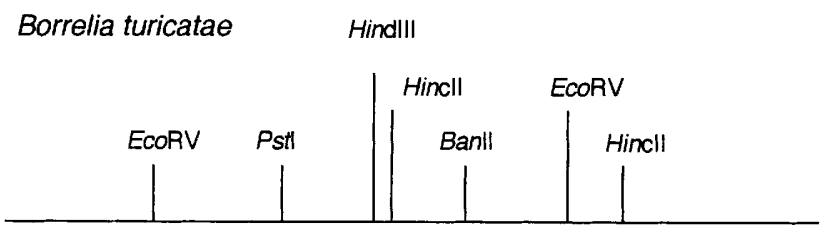

23S /5S rRNA genes

$1 \mathrm{~kb}$

FIG. 2. Hybridization of the rRNA gene probe with restriction enzyme digests of Borrelia genomic DNAs, physical maps of the regions surrounding the rRNA genes, and schematic representation of genomic hybridization. Genomic DNAs were extracted, digested with enzymes, electrophoresed, blotted, and hybridized with probes as described previously $(12,14)$. (A) Each genomic DNA was digested with HincII, electrophoresed in a $1 \%$ agarose gel, and blotted onto a nylon membrane (Zeta probe membrane; Bio-Rad Laboratories). Hybridization probe Sty was radiolabeled with $\left[\alpha{ }^{32} \mathrm{P}\right] \mathrm{dCTP}$ by using a random primer labeling kit according to the instructions of the manufacturer (Takara Shuzo) and was used as a probe. Lanes 1, 6, and 11, B. burgdorferi B31 ${ }^{\mathrm{T}}$; lane 2, strain NB103/1; lane 3, strain HT24; lane 4, strain HT31 ${ }^{\mathrm{T}}$; lane 5, strain Hk004; lane 7, B. coriaceae; lane 8, B. hermsii; lane 9, B. parkeri; lane 10, B. turicatae. (B) Genomic DNAs of strain HT31 ${ }^{\mathrm{T}}$ and B. turicatae were digested with enzymes, and physical maps of the regions surrounding the 23S and 5S rRNA genes of these organisms were constructed by digestion, partial digestion, and double digestion with enzymes and by genomic Southern hybridization as described previously $(12,15)$. Probes corresponding to the $5^{\prime}$ part of the $23 \mathrm{~S}$ rRNA gene (probe NP) and the 5S rRNA gene were also used, and the exact locations of the genes were determined as described previously (15). (C) Spirochete genomic DNAs were digested with EcoRV or Hincll. The resulting DNA fragments were electrophoresed, transferred, and hybridized with the 23S rRNA gene fragments of $B$. burgdorferi $\mathrm{B} 31^{\mathrm{T}}$ designated NP and Sty. The hybridization results obtained with the probes are presented schematically.

representatives of other Borrelia species $(23,37)$. The sequence which we obtained was 1,368 bp long and included positions 35 to 1408 ( $E$. coli numbering). This sequence was aligned and compared with the sequences of other Borrelia species by using the DNASTAR program. Nucleotide sequence pair similarity values for the sequences were calculated by using the Clustal method (16) (Table 3). A neighbor-joining phylogenetic tree constructed on the basis of the sequence similarity matrix data is shown in Fig. 4. According to this tree, the Borrelia strains which we compared could be divided into two major clusters. B. miyamotoi $\mathrm{HT} 31^{\mathrm{T}}$ belonged to a lineage distinct from the lineage that contained the previously described Lyme disease borreliae and to a cluster that included $B$. hermsii, B. anserina, and $B$. coriaceae. Our evolutionary analysis revealed that the members of this cluster are not closely related to each other. In contrast, North American strain DN127, which was isolated from Ixodes pacificus, and B. japonica $\mathrm{HO} 14^{\mathrm{T}}$ and IKA2 clustered in a distinct group along with the previously described Lyme disease borreliae. The tree clearly showed that the $B$. japonica strains are not closely related to all of the members of $B$. burgdorferi sensu lato which were compared. B. japonica seems to have diverged from $B$. burgdorferi sensu lato strains and to have adapted to $I$. ovatus ticks. B. japonica has been detected frequently in $I$. ovatus ticks collected in various locations in Japan $(29,34)$. Strain DN127 has been reported to be an unusual strain among the North American isolates $(38,48)$. Our phylogenetic analysis based on 16S rRNA gene sequences revealed that strain DN127 diverged at a level consistent with 

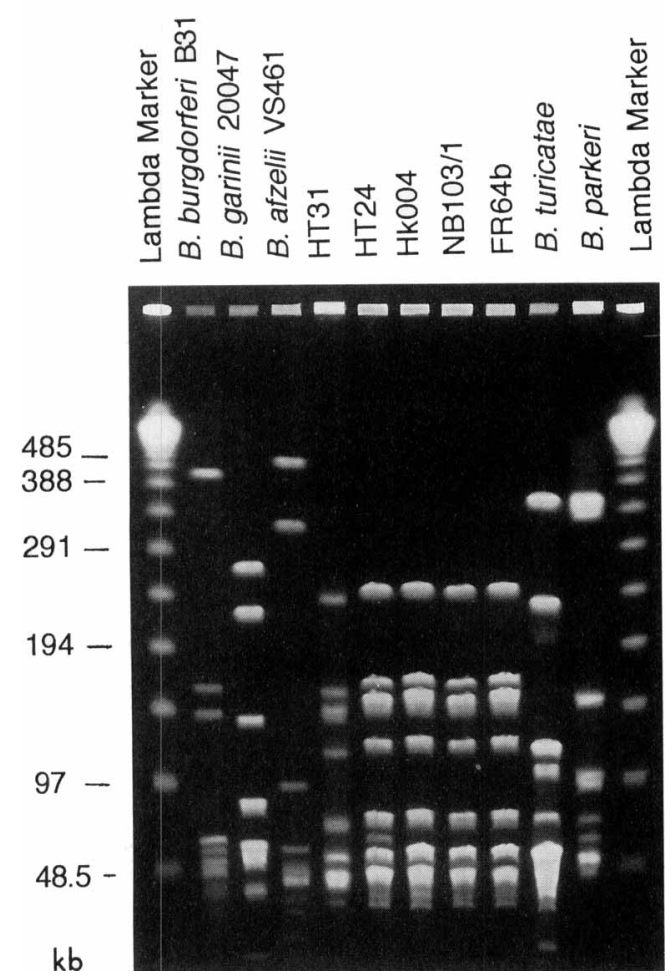

FIG. 3. PFGE of $M l u \mathrm{I}$ restriction digests of genomic DNAs. The genomic DNAs in agarose plugs were washed with $200 \mu \mathrm{l}$ of ice-cold digestion buffer, and the high-molecular-weight genomic DNAs in the plugs were cleaved with restriction enzyme $M l u \mathrm{I}$ as described by Davidson et al. (9). The genomic DNAs in the plugs were washed with $200 \mu$ of ice-cold digestion buffer for $30 \mathrm{~min}$ and then cleaved by exposing them to $50 \mathrm{U}$ of enzyme for $15 \mathrm{~h}$ at $37^{\circ} \mathrm{C}$ in $200 \mu \mathrm{l}$ of the buffer recommended by the supplier. The plugs were placed in wells containing $1.2 \%$ agarose (Pulsed Field Certified Agarose; Bio-Rad Laboratories) and were electrophoresed with a pulse time ramped from 3 to $50 \mathrm{~s}$ for $48 \mathrm{~h}$ at $150 \mathrm{~V}$ with a contour-clamped homogeneous electric field model DRII apparatus (Bio-Rad Laboratories). Molecular size markers consisting of lambda phage DNA concatemers (New England Biolabs) were used to calculate the sizes of the fragments. Restriction endonuclease $M l u I$ was purchased from Takara. The sizes of the fragments are indicated on the left.

the creation of a new species and that this organism is distinct from $B$. burgdorferi sensu stricto. Arbitrarily primed-PCR results also revealed that DN127 may belong to a distinct species (48). However, the level of relatedness determined by DNADNA hybridization experiments was borderline (38). Further studies will be needed to determine the position of strain DN127.

The $\mathrm{G}+\mathrm{C}$ contents of the genomic DNAs of members of the genus Borrelia are 27 to $32 \mathrm{~mol} \%$. The $\mathrm{G}+\mathrm{C}$ content of the DNA of strain HT31 ${ }^{\mathrm{T}}$ isolated from I. persulcatus in Japan was $28.6 \mathrm{~mol} \%$. All of our findings indicated that strain $\mathrm{HT} 31^{\mathrm{T}}$ is a representative of a new species belonging to the genus Borrelia.

The spirochete isolates described in this paper are quite different from the previously described Lyme disease borreliae and partially resemble relapsing fever borreliae or animal disease borreliae associated with Ornithodoros species ticks. The restriction sites of the new spirochete genomic DNA as determined by PFGE were distinct from the restriction sites of both types of previously described Borrelia species, but the flagellin gene sequence was more similar to the sequence found in the relapsing fever borreliae than to the sequence found in the previously described Lyme disease borreliae (unpublished data). The restriction enzyme maps of the rRNA genes of our isolates and the relapsing fever borreliae are quite similar. Our data demonstrated that the five spirochete isolates obtained in Hokkaido shared a few characteristics with some spirochetes associated with soft-bodied ticks. Several genetic parameters indicate that these isolates should be classified as members of a new species. Three of them originated from unfed $I$. persulcatus ticks, suggesting that the spirochete is transmitted transstadially during the tick molting process. The remaining two isolates originated from a bird-feeding tick and the blood of a rodent. Thus, the new spirochete is thought to be maintained in an enzootic cycle involving tick vectors and vertebrate reservoirs. Because there are no clinical records of relapsing fever in Hokkaido, we speculate that the new spirochete is not pathogenic for humans.

All species of the genus Borrelia are transmitted to vertebrates by hematophagous arthropods (4). The spirochetes are maintained in locations of endemicity of the disease by vectorreservoir transmission cycles involving several species of tick vectors. Two major groups of borreliae, relapsing fever borreliae and Lyme disease borreliae, have been well characterized. The borreliae associated with Lyme disease are found in a relatively limited number of Ixodes tick species. Borreliae associated with relapsing fever have been found in Ornithodoros or Argas tick species vectors or louse vectors, and some of the species exhibit complete specificity for their tick vectors (4). Relapsing fever is a well-studied disease, and its causative agent, $B$. hermsii, is of interest to microbiologists because of the molecular basis of its antigenic variation and the unique organization of its genes, linear chromosome, and minichromosomes (linear and circular plasmids). In contrast, Lyme disease is a recently recognized borreliosis with various inflammatory manifestations involving the skin, joints, heart, and central nervous system $(22,43)$. This disease is caused by $B$. burgdorferi sensu stricto in North America $(1,41)$ and by $B$. burgdorferi sensu stricto, $B$. garinii, and $B$. afzelii in the Palaearctic subregion $(17,36,46,49)$. It has been generally assumed that ticks belonging to the I. ricinus species complex (Ixodes scapularis and I. pacificus in North America and I. ricinus and I. persulcatus in Eurasia) are the vectors that transmit the disease to humans $(1,17,44)$.

Hard ticks (members of the family Ixodidae) are phylogenetically only distantly related to soft ticks, and as far as we know, the Lyme disease borreliae definitely differ from the relapsing fever borreliae in their arthropod vectors. Our results, therefore, contain important data on the evolution of borreliae and the adaptation of borreliae to vector ticks and provide a useful model for finding clues concerning the adaptive evolution of organisms. If we assume that Borrelia species

TABLE 2. Levels of DNA relatedness among Borrelia species

\begin{tabular}{|c|c|c|c|}
\hline \multirow{2}{*}{$\begin{array}{c}\text { Source of } \\
\text { unlabeled DNA }\end{array}$} & \multicolumn{3}{|c|}{$\begin{array}{l}\text { Relative binding ratios (\%) with the following } \\
\text { sources of labeled DNA: }\end{array}$} \\
\hline & Strain HT31 ${ }^{\mathrm{T}}$ & B. burgdorferi $\mathrm{B} 31^{\mathrm{T}}$ & B. hermsii \\
\hline B. miyamotoi $\mathrm{HT} 31^{\mathrm{T}}$ & 100 & 13 & 45 \\
\hline B. miyamotoi FR64b & 100 & 14 & 45 \\
\hline B. burgdorferi $\mathrm{B} 31^{\mathrm{T}}$ & 10 & 100 & 21 \\
\hline B. garinii $20047^{\mathrm{T}}$ & 13 & 65 & 27 \\
\hline B. afzelii $\mathrm{VS} 461^{\mathrm{T}}$ & 8 & 57 & 16 \\
\hline B. japonica Am105 & 9 & 48 & 17 \\
\hline B. hermsii & 44 & 21 & 100 \\
\hline B. turicatae & 41 & $\mathrm{ND}^{a}$ & ND \\
\hline B. parkeri & 51 & ND & ND \\
\hline B. coriaceae $\mathrm{Co} 53$ & 41 & ND & ND \\
\hline B. anserina & 24 & ND & ND \\
\hline
\end{tabular}

${ }^{a} \mathrm{ND}$, not determined. 
TABLE 3. 16S rRNA sequence similarity matrix for Borrelia isolates

\begin{tabular}{|c|c|c|c|c|c|c|c|c|c|c|c|}
\hline \multirow[b]{2}{*}{ Strain or species } & \multicolumn{11}{|c|}{$\% 16 \mathrm{~S}$ rRNA sequence similarity with: } \\
\hline & $\begin{array}{l}\text { Strain } \\
1352\end{array}$ & $\begin{array}{l}\text { Strain } \\
\mathrm{B} 31^{\mathrm{T}}\end{array}$ & $\begin{array}{c}\text { Strain } \\
\text { DN127 }\end{array}$ & $\begin{array}{c}\text { Strain } \\
\text { G1 }\end{array}$ & $\begin{array}{l}\text { Strain } \\
\text { HO14 }\end{array}$ & $\begin{array}{l}\text { Strain } \\
\text { IKA2 }\end{array}$ & $\begin{array}{l}\text { Strain } \\
\text { Ip3 }\end{array}$ & $\begin{array}{l}\text { Strain } \\
\text { Co53 }\end{array}$ & $\begin{array}{c}\text { Strain } \\
\text { HS1 }\end{array}$ & $\begin{array}{c}\text { Strain } \\
\text { HT31 }^{\mathrm{T}}\end{array}$ & B. anserina \\
\hline B. burgdorferi 1352 & 100 & & & & & & & & & & \\
\hline B. burgdorferi $\mathrm{B} 31^{\mathrm{T}}$ & 96.7 & 100 & & & & & & & & & \\
\hline Borrelia sp. strain DN127 & 95.7 & 95.0 & 100 & & & & & & & & \\
\hline B. garinii $\mathrm{G} 1$ & 98.6 & 96.2 & 95.5 & 100 & & & & & & & \\
\hline B. japonica $\mathrm{HO}^{\mathrm{T}}$ & 95.5 & 94.1 & 97.6 & 95.4 & 100 & & & & & & \\
\hline B. japonica IKA2 & 94.7 & 93.8 & 96.3 & 94.9 & 97.3 & 100 & & & & & \\
\hline B. afzelii Ip 3 & 98.3 & 95.7 & 95.0 & 98.1 & 95.1 & 94.4 & 100 & & & & \\
\hline B. coriaceae Co53 & 93.4 & 90.8 & 90.4 & 93.3 & 90.5 & 89.7 & 93.2 & 100 & & & \\
\hline B. hermsii HS1 & 93.7 & 91.1 & 90.5 & 93.2 & 90.5 & 89.8 & 93.7 & 97.6 & 100 & & \\
\hline B. miyamotoi $\mathrm{HT} 31^{\mathrm{T}}$ & 94.8 & 93.0 & 92.7 & 94.7 & 91.8 & 91.9 & 94.8 & 94.3 & 94.5 & 100 & \\
\hline B. anserina & 93.2 & 91.1 & 90.3 & 93.0 & 90.1 & 89.4 & 93.4 & 96.7 & 94.1 & 94.1 & 100 \\
\hline
\end{tabular}

have a common ancestor, we can speculate that the spirochete found in Hokkaido is a descendant adapted to hard-bodied ixodid ticks that has some characteristics of relapsing fever borreliae. Recently, Carter et al. (8) and Margolis et al. (24) described the similarity between the outer surface protein $(o s p C)$ gene of Lyme disease borreliae and the variable major protein $(\mathrm{vmp})$ genes of relapsing fever borreliae (B. hermsii). The observations of these authors suggest that these two groups of pathogens evolved from a common ancestor but have adapted to various arthropod and vertebrate hosts. Further phylogenetic studies will be necessary to better understand the diversity of Borrelia species. Moreover, the susceptibility of members of the tick families Argasidae and Ixodidae to various Borrelia species should be investigated under laboratory conditions; the results should provide useful information concerning the adaptation of borreliae to tick vectors.

Description of Borrelia miyamotoi sp. nov. Borrelia miyamotoi (mi. ya. mo' toi. M.L. gen. n. miyamotoi, of Miyamoto, in honor of Kenji Miyamoto, the entomologist who first isolated spirochetes from ixodid ticks in Hokkaido, Japan). Morphology as described previously for the genus (20). Culture properties as described previously for $B$. burgdorferi sensu lato (3, 18 ). The single gene cluster for $23 \mathrm{~S}$ and $5 \mathrm{~S}$ rRNAs is separated from the 16S rRNA gene. Reacts in Western blots with monoclonal antibody $\mathrm{H} 9724$ and yields a $38-\mathrm{kDa}$ band. No reactivity is observed with monoclonal antibody H5332. This species can also be differentiated from other Borrelia species on the basis of DNA-DNA hybridization results and by the sequence of its $16 \mathrm{~S}$ rRNA genes.

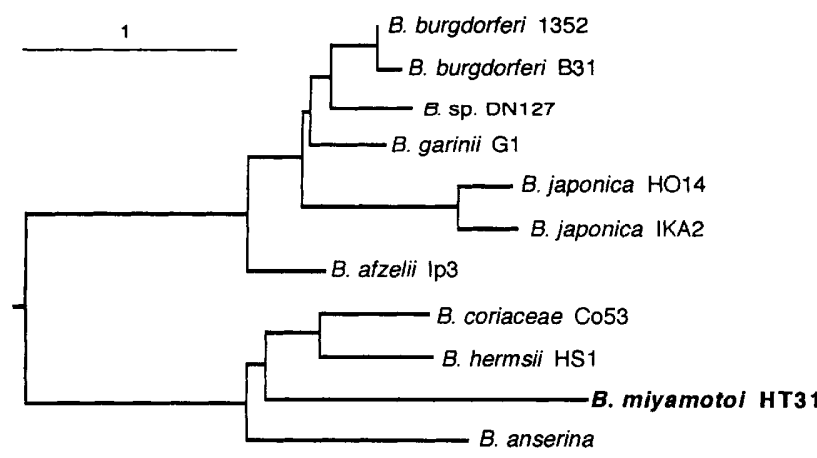

FIG. 4. Phylogenetic tree for Borrelia isolates. The phylogenetic tree was constructed as described in the text by using 16S rRNA gene sequences. Bar = $1 \%$ difference between sequences, as determined by measuring the lengths of the horizontal lines connecting two species.
The $\mathrm{G}+\mathrm{C}$ content of the DNA is 28 to $29 \mathrm{~mol} \%$.

The type strain is strain HT31, which has been deposited in the Japan Collection of Microorganisms (RIKEN) as strain JCM 9579. Strain HT31 ${ }^{\mathrm{T}}$ was isolated from an $I$. persulcatus tick in Hokkaido, Japan. B. miyamotoi has been isolated from unfed $I$. persulcatus ticks, from the blood of a rodent, and from a tick that fed on a bird in Hokkaido.

\section{ACKNOWLEDGMENTS}

We deeply thank Tom G. Schwan (Rocky Mountain Laboratories) for critically reading the manuscript, for useful comments, and for the P39 gene clone and Guy Baranton (Institut Pasteur) for critically reading the manuscript and for useful comments. We also thank Akiko Hamase for PCR amplification and cloning, Yasuyo Koreki for sequencing, and Hirofumi Inoue for HPLC.

This study was supported in part by Grants-in-Aid for Scientific Research 05670218, 06044191, and 06640912 from the Ministry of Education, Science, and Culture of Japan. M.M. and D.R. were supported by grant AI34829 from the National Institutes of Health to John Welsh.

\section{REFERENCES}

1. Anderson, J. F. 1989. Epizootiology of Borrelia in Ixodes tick vectors and reservoir hosts. Rev. Infect. Dis. 11(Suppl. 6):s1451-s1459.

2. Baranton, G., D. Postic, I. Saint Girons, P. Boerlin, J. C. Piffaretti, M. Assous, and P. A. D. Grimont. 1992. Delineation of Borrelia burgdorferi sensu stricto, Borrelia garinii sp. nov., and group VS461 associated with Lyme borreliosis. Int. J. Syst. Bacteriol. 42:378-383.

3. Barbour, A. G. 1984. Isolation and cultivation of Lyme disease spirochetes. Yale J. Biol. Med. 57:521-525.

4. Barbour, A. G., and S. F. Hayes. 1986. Biology of Borrelia species. Microbiol. Rev. 50:381-400.

5. Barbour, A. G., S. F. Hayes, R. A. Heiland, M. E. Schrumpf, and S. L. Tessier. 1986. A Borrelia-specific monoclonal antibody binds to a flagellar epitope. Infect. Immun. 52:549-554.

6. Burgdorfer, W., R. S. Lane, A. G. Barbour, R. A. Gresbrink, and J. R. Anderson. 1985. The western black-legged tick, Lxodes pacificus: a vector of Borrelia burgdorferi. Am. J. Trop. Med. Hyg. 34:925-930.

7. Canica, M. M., F. Nato, L. du Merle, J. C. Mazie, G. Baranton, and D. Postic. 1993. Monoclonal antibodies for identification of Borrelia afzelii sp. nov. associated with late cutaneous manifestations of Lyme borreliosis. Scand. J. Infect. Dis. 25:441-448.

8. Carter, C. J., S. Bergstrom, S. J. Norris, and A. G. Barbour. 1994. A family of surface-exposed proteins of 20 kilodaltons in the genus Borrelia. Infect. Immun. 62:2792-2799.

9. Davidson, B. E., J. MacDougall, and I. Saint Girons. 1992. Physical maps of the linear chromosome of the bacterium Borrelia burgdorferi 212. J. Bacteriol. 174:3766-3774.

10. Fukunaga, M., I. Horie, and I. Mifuchi. 1990. Isolation and characterization of the 5S rRNA gene of Leptospira interrogans. J. Bacteriol. 172:3264-3268.

11. Fukunaga, M., and I. Mifuchi. 1989. Unique organization of Leptospira interrogans rRNA genes. J. Bacteriol. 171:5763-5767.

12. Fukunaga, M., and M. Sohnaka. 1992. Tandem repeat of the $23 \mathrm{~S}$ and $5 \mathrm{~S}$ ribosomal RNA genes in Borrelia burgdorferi, the etiological agent of Lyme disease. Biochem. Biophys. Res. Commun. 183:952-957. 
13. Fukunaga, M., M. Sohnaka, M. Nakao, and K. Miyamoto. 1993. Evaluation of genetic divergence of borrelial isolates from Lyme disease patients in Hokkaido, Japan, by rRNA gene probes. J. Clin. Microbiol. 31:2044-2048.

14. Fukunaga, M., M. Sohnaka, and Y. Yanagihara. 1993. Analysis of Borrelia species associated with Lyme disease by rRNA gene restriction fragment length polymorphism. J. Gen. Microbiol. 139:1141-1146.

15. Fukunaga, M., Y. Yanagihara, and M. Sohnaka. 1992. The 23S/5S ribosomal RNA genes $(r l / r r f)$ are separate from the 16S ribosomal RNA gene $(r r s)$ in Borrelia burgdorferi, the aetiological agent of Lyme disease. J. Gen. Microbiol. 138:871-877.

16. Higgines, D. G., A. J. Bleasby, and R. Fuchs. 1992. CLUSTAL V: improved software for multiple sequence alignment. Comput. Appl. Biosci. 8:189-191.

17. Jaenson, T. G. T. 1991. The epidemiology of Lyme borreliosis. Parasitol. Today 7:39-45.

18. Johnson, R. C., F. W. Hyde, G. P. Schmid, and D. J. Brenner. 1984. Borrelia burgdorferi sp. nov.: etiological agent of Lyme disease. Int. J. Syst. Bacteriol. 34:496-497.

19. Kawabata, H., T. Masuzawa, and Y. Yanagihara. 1993. Genomic analysis of Borrelia japonica sp. nov. isolated from Ixodes ovatus in Japan. Microbiol. Immunol. 37:843-848.

20. Kelly, R. T. 1984. Borrelia, p. 57-62. In N. R. Krieg and J. G. Holt (ed.), Bergey's manual of systematic bacteriology, vol. 1. The Williams \& Wilkins Co., Baltimore.

21. Liveris, D., A. Gazumyan, and I. Schwartz. 1995. Molecular typing of Borrelia burgdorferi sensu lato by $\mathrm{PCR}$-restriction fragment length polymorphism analysis. J. Clin. Microbiol. 33:589-595.

22. Logigian, E. L., R. F. Kaplan, and A. C. Steere. 1990. Chronic neurologic manifestations of Lyme disease. N. Engl. J. Med. 323:1438-1444.

23. Marconi, R. T., and C. F. Garon. 1992. Phylogenetic analysis of the genus Borrelia: a comparison of North American and European isolates of Borrelia burgdorferi. J. Bacteriol. 174:241-244.

24. Margolis, N., D. Hogan, C. J. W., T. G. Schwan, and P. A. Rosa. 1994. Homology between Borrelia burgdorferi OspC and members of the family of Borrelia hermsii variable major proteins. Gene 143:105-110.

25. Masuzawa, T., Y. Okada, Y. Beppu, T. Oku, F. Kawamori, and Y. Yanagihara. 1991. Immunological properties of Borrelia burgdorferi isolated from the Ixodes ovatus in Shizuoka, Japan. Microbiol. Immunol. 35:913-919.

26. Meyer, S. A., and K. H. Schleifer. 1978. Deoxyribonucleic acid reassociation in the classification of coagulase positive staphylococci. Arch. Microbiol. 117:183-188.

27. Miyamoto, K., M. Nakao, H. Fujita, and F. Sato. 1993. The ixodid ticks on migratory birds in Japan and the isolation of Lyme disease spirochetes from bird-feeding ticks. Jpn. J. Sanit. Zool. 44:315-326.

28. Miyamoto, K., M. Nakao, N. Sato, and M. Mori. 1991. Isolation of Lyme disease spirochetes from an ixodid tick in Hokkaido, Japan. Acta Trop. 49:65-68.

29. Miyamoto, K., M. Nakao, K. Uchikawa, and H. Fujita. 1992. Prevalence of Lyme borreliosis spirochetes in ixodid ticks of Japan, with special reference to a new potential vector, Ixodes ovatus (Acari: Ixodidae). J. Med. Entomol. 29:216-220.

30. Miyamoto, K., and K. Takahashi. 1990. Human ixodiasis in Hokkaido: case report and questionnaire for the forestry organization. Jpn. J. Sanit. Zool. 41:59-62.

31. Nakao, M., and K. Miyamoto. 1993. Reservoir competence of the wood mouse, Apodemus speciosus ainu, for the Lyme disease spirochete, Borrelia burgdorferi, in Hokkaido, Japan. Jpn. J. Sanit. Zool. 44:69-84.

32. Nakao, M., K. Miyamoto, and M. Fukunaga. 1994. Lyme disease spirochetes in Japan: enzootic transmission cycles in birds, rodents, and Ixodes persulca tus ticks. J. Infect. Dis. 170:878-882.

33. Nakao, M., K. Miyamoto, N. Kawaguchi, Y. Hashimoto, and H. lizuka. 1992 Comparison of Borrelia burgdorferi isolated from humans and ixodid ticks in Hokkaido, Japan. Microbiol. Immunol. 36:1189-1193.

34. Nakao, M., K. Miyamoto, K. Uchikawa, and H. Fujita. 1992. Characterization of Borrelia burgdorferi isolated from Ixodes persulcatus and Ixodes ovatus ticks in Japan. Am. J. Trop. Med. Hyg. 47:505-511.

35. Nomura, M., and E. A. Morgan. 1977. Genetics of bacterial ribosomes. Annu. Rev. Genet. 11:297-347.

36. Park, K.-H., W.-H. Chang, and T. G. Schwan. 1993. Identification and characterization of Lyme disease spirochetes, Borrelia burgdorferi sensu lato, isolated in Korea. J. Clin. Microbiol. 31:1831-1837.

37. Paster, B. J., F. E. Dewhirst, W. G. Weisburg, L. A. Tordoff, G. J. Fraser, R. B. Hespell, T. B. Stanton, L. Zablen, L. Mandelco, and C. R. Woese. 1991. Phylogenetic analysis of the spirochetes. J. Bacteriol. 173:6101-6109.

38. Postic, D., M. V. Assous, P. A. D. Grimont, and G. Baranton. 1994. Diversity of Borrelia burgdorferi sensu lato evidenced by restriction fragment length polymorphism of $r f(5 S)-r r l(23 S)$ intergenic spacer amplicons. Int. J. Syst. Bacteriol. 44:743-752.

39. Saitou, N., and M. Nei. 1987. The neighbor-joining method: a new method for reconstructing phylogenetic trees. Mol. Biol. Evol. 4:406-425.

40. Schwan, T. G., M. E. Schrumpf, K. L. Gage, and R. D. Gilmore, Jr, 1992 Analysis of Leptospira spp., Leptonema illini, and Rickettsia rickettsii for the 39-kilodalton antigen (P39) of Borrelia burgdorferi. J. Clin. Microbiol. 30: 735-738.

41. Schwan, T. G., M. E. Schrumpf, R. H. Karstens, J. R. Clover, J. Wong, M. Daugherty, M. Struthers, and P. A. Rosa. 1993. Distribution and molecular analysis of Lyme disease spirochetes, Borrelia burgdorferi, isolated from ticks throughout California. J. Clin. Microbiol. 31:3096-3108.

42. Schwartz, J. J., A. Gazumyan, and I. Schwartz. 1992. rRNA gene organization in the Lyme disease spirochete, Borrelia burgdorferi. J. Bacteriol. 174: $3757-3765$.

43. Steere, A. C., V. P. Berardi, K. E. Weeks, E. L. Logigian, and R. Ackermann 1990. Evaluation of the intrathecal antibody response to Borrelia burgdorfen as a diagnostic test for Lyme neuroborreliosis. J Infect. Dis. 161:1203-1209.

44. Szczepanski, A., and J. L. Benach. 1991. Lyme borreliosis: host responses to Borrelia burgdorferi. Microbiol. Rev. 55:21-34.

45. Takahashi, Y., M. Sohnaka, M. Nakao, K. Miyamoto, and M. Fukunaga. 1993. Characterization of Borrelia species isolated from ixodid ticks, Ixodes ovatus. Microbiol. Immunol. 37:721-727.

46. Wallich, R., C. Helmes, U. E. Schaible, Y. Lobet, S. E. Moter, M. D. Kramer, and M. M. Simon. 1992. Evaluation of genetic divergence among Borrelia burgdorferi isolates by use of OspA, fla, HSP60, and HSP70 gene probes. Infect. Immun. 60:4856-4866.

47. Wayne, L. G., D. J. Brenner, R. R. Colwell, P. A. D. Grimont, O. Kandler, M. I. Krichevsky, L. H. Moore, R. G. E. Murray, E. Stackebrandt, M. P. Starr, and H. G. Trüper. 1987. Report of the Ad Hoc Committee on Reconciliation of Approaches to Bacterial Systematics. Int. J. Syst. Bacteriol. 37:463-464

48. Welsh, J., C. Pretzman, D. Postic, I. Saint Girons, G. Baranton, and M. McClelland. 1992. Genomic fingerprinting by arbitrarily primed polymerase chain reaction resolves Borrelia burgdorferi into three distinct phyletic groups. Int. J. Syst. Bacteriol. 42:370-377.

49. Wilske, B., V. Preac-Mursic, U. B. Göbel, B. Graf, S. Jauris, E. Soutschek, E Schwab, and G. Zumstein. 1993. An OspA serotyping system for Borrelia burgdorferi based on reactivity with monoclonal antibodies and OspA sequence analysis. J. Clin. Microbiol. 31:340-350. 